\title{
Procedural aspects of healthcare quality control in Latvia and its effect on legal protection of patients
}

\author{
A. Liepins, O. Joksts, and J. Vetra \\ Rīga Stradiņš University, Riga, Latvia
}

\begin{abstract}
According to the European Commission data, $8-12 \%$ of patients cared for in hospitals throughout the European Union have suffered accidents related to the healthcare provided for them. The Directive 2011/24/EU of the European Parliament and Council of $9^{\text {th }}$ March 2011 on the application of patients' rights in cross-border healthcare provides that the Member States should ensure that patients have easily accessible and transparent appeal procedures and mechanisms that provide possibilities for legal remedies in cases of inflicted harm during medical treatment according to regulations of the respective Member State. Healthcare quality control mechanisms are intended for two major purposes: to identify accidents that have occurred during medical treatment and to prevent similar accidents from reoccurring in the future. The aim of this article is to evaluate, firstly, the procedural aspects of healthcare quality control mechanisms in Latvia and, secondly, how healthcare quality control mechanisms have been affected with the implementation of the Directive 2011/24/EU in Latvian legal order, providing for a specific legal remedy - the newly created Medical risk fund. Conclusions are made on the procedural nature of the patients' right to submit complaints and also the developments in Latvian court practice related to the healthcare quality control. The authors have also analysed regulations related to the Medical risk fund, its influence on the civil liability mechanisms of medical practitioners, as well as the patient's right to obtain just compensation for the harm inflicted to his health and the legal nature of opinions of the Health Inspectorate of Latvia.
\end{abstract}

\section{Introduction}

Healthcare quality is a vital matter for the society as a whole. According to the European Commission data, $8-12 \%$ of patients cared for in hospitals throughout the European Union have suffered accidents related to the healthcare provided for them. In cases when a medical practitioner has provided poor healthcare to a patient, this practitioner may be subjected to (1) criminal or (2) administrative liability and/or (3) civil liability and/or (4) disciplinary liability, and/or (5) professional liability, and/or (6) liability for the breach of a public law contract.

The European Charter of Patients' Rights, which is a doctrinal document [6] and which specifies the scope of Article 35 of the Charter of Fundamental Rights of the European 
Union [3], also provides the right to healthcare quality standards, the right to safety during medical treatment as well as the right to submit complaints regarding this treatment.

The Directive 2011/24/EU of the European Parliament and Council of $9^{\text {th }}$ March 2011 on the application of patients' rights in cross-border healthcare (hereinafter - the Directive) provides that the Member States have to ensure that patients have easily accessible and transparent appeal procedures and mechanisms that provide possibilities for legal remedies in cases of inflicted harm during medical treatment according to regulations of the respective Member State. As a result of this, on $25^{\text {th }}$ October 2013 the Medical risk fund (Veselības riska fonds) concept was implemented in Latvia, which was based on the Swedish and Danish examples. Functioning of the Medical risk fund is ensured by two state institutions that are directly subordinated to the Ministry of Health of the Republic of Latvia: the Health Inspectorate and the National Health Service.

This article offers a detailed research on the following issues:

1. Administrative procedural aspects of the healthcare quality control;

2. Scope of patients' right to submit complaints in Latvia;

3. Available court control in healthcare violation cases;

4. Civil law aspects of the healthcare quality control.

In addition, it should be noted that the topicality of this article is based on the recent changes in administrative and civil liability of medical practitioners in Latvia.

\section{Administrative procedures of healthcare quality control}

Healthcare quality control in Latvia is carried out via administrative procedures conducted by the Health Inspectorate, which is directly subordinated to the Ministry of Health [10]. The Health Inspectorate monitors and controls the professional quality of healthcare, without any specific complaints from third parties regarding the quality of healthcare. Despite the fact that the Health Inspectorate has put forward as its priority objective to establish a united healthcare facility monitoring system, which would ensure a long-term healthcare facility monitoring program instead of examining individual cases [1], nevertheless the major importance remains with complaints submitted by patients, since these signal of a possible violation of the healthcare quality in a specific place and time. The Health Inspectorate's replies to submitted complaints, as well as its issued administrative acts and performed factual conduct are subject to a control in court, when there is a dispute of the lawfulness or validity of these replies, administrative acts or factual conduct.

On $1^{\text {st }}$ March 2010 the new Law on the Rights of Patients [8] came into force, which was intended as a unified legislative act for the protection of the rights of patients, ensuring compliance with the rights and legitimate interests of patients in matters related to medical treatment. Until $1^{\text {st }}$ March 2010 the regulation of patients' rights was partly provided for in the Medical Treatment Law [9].

Until $1^{\text {st }}$ March 2010 Article 22 of the Medical Treatment Law provided for the right of the patient to submit complaints and to receive a healthcare quality evaluation of the provided medical treatment, however, stating that such evaluation can be received in cases specifically provisioned for in the respective legal acts of the specific Member state. Since $1^{\text {st }}$ March 2010 these relevant rights of patients are enshrined in Article 18, paragraph 3 of the Law on the Rights of Patients. The right of a patient to submit complaints is considered as patient's procedural right, which also provides an opportunity for the protection of other patients' rights in cases when such rights are not ensured. 
Consequently, when reviewing a patient's complaint, the Health Inspectorate examines the quality of healthcare provided to patient and - as a result of that - is authorized to make three different decisions, which have different legal consequences, that is, to acknowledge:

1) that there has been a violation of patient's healthcare and, consequently, to satisfy the submitted complaint in full. In this case the Health Inspectorate whether initiates an administrative violation procedure or acknowledges that a criminal offence has been committed. In the latter case this legal opinion is sent to the police authorities in order for them to decide whether criminal proceedings should be initiated (here it must be stressed that criminal matters are not examined within the scope of this article);

2) that there has been a violation of patient's healthcare and, consequently, to satisfy the submitted complaint in part and to initiate an administrative violation procedure, while partly acknowledging what is not to be considered as a violation of patient's healthcare. In this case the Health Inspectorate initiates an administrative violation procedure and - regarding the decision in part where there has not been a violation of patient's healthcare - it informs the submitter that the complaint has been partly rejected due to the fact that in this part there has not been a violation of patient's healthcare;

3) that there has been no violation of patient's healthcare at all. In this case the Health Inspectorate informs the submitter that there has not been a violation of patient's healthcare.

It should be noted that the various decisions of the Health Inspectorate procedurally differ from each other. The same applies to the procedures for submitting an appeal.

The Health Inspectorate decision to initiate an administrative violation procedure (investigation) is of a criminal law nature. In several cases the European Court of Human Rights has stated that administrative offence cases are similar to criminal cases ("Pfarrmeier v. Austria", "Engel and others v. the Netherlands", "Zolotukhin v. Russia", etc.) because of the fact that a person has a right to equal procedural guarantees as in criminal proceedings. In these kinds of procedures the dominant principle is the adversarial principle. If a medical practitioner is found guilty in administrative violation procedure, then the Health Inspectorate is entitled to impose an administrative sanction (quasi-criminal penalty) for committing a violation of patient's healthcare [16]. In addition it must be pointed out that from $1^{\text {st }}$ July 2012 onwards an administrative offence procedure reform is being carried out in Latvia, during which the previously mentioned opinion has been maintained that administrative violation procedures have a criminal law nature and that during the investigation of a case the respective defendant is entitled to criminal procedural guarantees. At the same time it must be pointed out that the scope of the patients' rights has not been significantly affected in this reform.

The Health Inspectorate's decision that there has not been a violation of patient's healthcare is considered as a factual conduct within the scope of the Administrative Procedure Law. Until $1^{\text {st }}$ March 2010 during administrative proceedings a person was entitled to submit a complaint for this factual conduct in the administrative court, which would then review the case in three instances: the court of first instance, the court of appeal and the court of Cassation. However, from $1^{\text {st }}$ March 2010 during administrative proceedings the Health Inspectorate examines the complaints of healthcare violations in accordance with the Law on Submissions [7, 18]. Since this date the actions of an institution initially were controlled by two administrative court instances (the court of first instance and the court of Cassation), but after regulation amendments on March $15^{\text {th }} 2012$ (which came into force on April 18 $8^{\text {th }}$ 2012) the cases are reviewed only in the first instance court - the District Administrative Court. Consequently, during the period from March $1^{\text {st }}$ 
2010 until April $18^{\text {th }} 2012$ the scope of patients' rights to submit applications to the administrative courts have been significantly narrowed.

Furthermore in the annotation of the law amendments of March $15^{\text {th }} 2012$ [5] it was stated that the applications of violations of the Law on Submissions shall be reviewed in the District Administrative Court and that the rulings of this particular court will not be subject to an appeal. Such choice was made in order to reduce the large burden of cases on courts, which, however, cannot lead to a violation of person's rights, since the Law on Submissions is not intended for the protection of subjective public rights, but offers a possibility for persons to participate in the public administration.

The subjective public rights are conferred to a person by legal norms. According to the protective provisions theory, a public law norm grants the applicant subjective public rights if the norm:

1) imposes an obligation to take a certain action or refrain from it;

2) this obligation serves also for protection of individual rights;

3) the applicant is among the eligible (protected) group of persons [19].

Consequently, it must be concluded that the thesis included in the annotation of the law amendments that the Law on Submissions is not intended for the protection of subjective public rights, but instead for the participation in the public administration, is not acceptable. However the amendments in the Law on Submissions should not be considered as a mistake. The authors' point of view is that a mistake was indeed made by adopting Article 18, paragraph 3 of the Law On the Rights of Patients, which provides that the Health Inspectorate's reply to a patient's complaint must be given in accordance with the Law On Submissions, arguing that the patient's complaint belongs to the subjective public law, which serves as an individual legal remedy for the patient. The authors believe that Article 18, paragraph 3 of the Law On the Rights of Patients should be amended, excluding from this legal norm the reference that the appeal must be made in accordance with the Law On Submissions.

\section{Latvian court control in healthcare violation cases}

In its rulings the Supreme Court of Latvia has stated that "the court is required to examine whether the Health Inspectorate, which controls the enforcement of regulations in healthcare related matters, has ascertained all aspects of the case and made reasonable conclusions [...]. The court itself cannot evaluate the quality of healthcare provided" [2022]. In these and many other rulings the Supreme Court has accepted the argumentation of the Health Inspectorate's decisions that were appealed before it, that evaluation of such an appeal clearly requires special knowledge in medicine.

The question whether the court itself cannot evaluate the quality of healthcare provided, is a question of debate. During an administrative violation procedure the Health Inspectorate performs a healthcare quality expertise, forms a legal opinion (which by its legal nature is considered as an evidence - an opinion of an expert which consists of the healthcare violation description within the light of medical science), prepares the protocol of an administrative violation, performs various other investigative actions and, consequently, makes a decision on the administrative liability of the respective medical practitioner. It is beyond any doubt that the judge does not have the required special knowledge in medical science, while the medical practitioners - experts of the Health Inspectorate have such special knowledge. However, a lack of special knowledge cannot be an obstacle to evaluate correlations, particularly if the party provides sufficient evidence that the legal opinion passed by the Health Inspectorate is unreasonable. 
It should be pointed out that in its rulings the Supreme Court has sometimes distanced from the regular practice that the court does not evaluate the quality of healthcare provided. In these rulings the Supreme Court has stated that "the legal opinion lacks correlation between the information provided and conclusions" [24, 25]. Still, for the court to ascertain existence of factual conduct in a particular case, it would need special knowledge, in order to be able to evaluate the correlation or lack of argumentation, which the court does not have.

Thereby it is evident that the court practice in healthcare violation cases is not consistent. As a secondary consequence of this, a person cannot safely conduct their behaviour: the person must be able - if need be, by receiving advice from a specialist - to predict the consequences of her actions in a reasonable way. However, the primary problem of such inconsistent court practice is directly connected with the society's general confidence in court.

The authors believe that the court should not generally distance itself from evaluations in medical or specific scientific matters. However, that does not mean that judges should be specialists in all branches of science. Still, in unclear matters the courts should use the available procedural instruments, such as an additional expertise and/or a repeated expertise, consequently interrogating the relevant experts. Such an approach to this matter in Latvia has not been exercised yet. As a result of the procedural reform of administrative violations law, since July $1^{\text {st }} 2012$ adversarial principle is being implemented in these cases and so the courts are limited in ex officio appointing an expertise and inviting experts to the court hearings. However, the court may use these procedural instruments by referring to the legal clarification principle when explaining to the parties involved their procedural rights to submit relevant requests during the trial.

In cases when the Health Inspectorate has decided that there has not been a violation of healthcare quality, the court (in an administrative procedure) is not limited in ex officio appointing an expertise and inviting experts to the court hearings, because administrative proceedings must be carried out in accordance with the principle of objective investigation. Taking into consideration that such cases are reviewed in the court of first instance, the authors believe that it is of a particular importance to use these procedural instruments in order to determine whether there has been or has not been a violation of healthcare.

However, an additional expertise or a repeated expertise must not be appointed when a party simply raises objections against the expertise provided by the Health Inspectorate. A criteria to determine, whether an additional expertise or a repeated expertise should be appointed, is the already existing argument in court practice, which consists of a lack of correlation between the information provided and the conclusions made. It was exactly this argument, which was used in a civil case, where a patient brought an action against four medical institutions for the harm inflicted to her health. In this particular case the court regardless of the Health Inspectorate's legal opinion which was in favour of the patient did not find any connection between the actions of respective medical practitioners and the patient's course of illness and, consequently, her disability. In this particular case the court of appeal stated that "in the file of the case there is no evidence that would conclusively confirm that during the period of [...] in the hospital of V. there were mistakes conceded that would be in a correlation with the damage of patient's health, mutilation and the subsequent moral and material damage" [23]. 


\section{Civil law aspects of the healthcare quality control}

In most cases, violation of healthcare quality leads to inflicting harm to the patient. According to Article 2347 of the Civil Law of the Republic of Latvia [12] the patient has the right to just compensation for the inflicted bodily injury, which includes:

1) expenses for medical treatment;

2) potential loss of income (pursuant to discretion of the court);

3) remuneration (material compensation) for the suffered moral injury.

For the patient to be eligible to compensation, he must prove an existing correlation between the harm inflicted to his health and a wrongful act during the medical treatment. In Latvia such evidence may be acquired in three possible ways:

1) healthcare quality expertise and, consequently, a legal opinion of the Health Inspectorate;

2) expertise of State Centre for Forensic Medical Examination;

3) expertise of a medical commission appointed by court.

Furthermore, it must be noted that healthcare quality expertise theoretically may be performed by medical commission or a foreign forensic institution chosen by patient himself. However, to the authors' knowledge so far such situations have not occurred in Latvia.

As mentioned in the introduction of this article, on October $25^{\text {th }} 2013$ the Directive was implemented in Latvian legal system. Among other things, the Directive provisions an obligation of the Member States towards patients (including patients from other Member States) to ensure accessible procedures and mechanisms for submitting complaints, which would allow a patient to seek legal remedies in cases when the provided healthcare has inflicted harm to him. As a result of this, on October $25^{\text {th }} 2013$, on basis of the Swedish and Danish experience, there were made amendments in the Law on the Rights of Patients, providing for a specific legal remedy - the Medical risk fund.

Up until October $25^{\text {th }} 2013$, a person, who had suffered from a wrongful act during the healthcare provided, claimed the compensation from the respective medical institution or medical practitioner, which or who had provided the healthcare. In case of a dispute such actions in court were reviewed in a civil procedure and in a three level court system. Currently Latvian courts still review cases of pecuniary claims for the harm inflicted to patient's life or health until October $25^{\text {th }} 2013$. However, starting from this date the harm inflicted to patient's life or health is being solved via a specific administrative mechanism for the protection of rights of patients, the Medical risk fund.

The general principles of the Medical risk fund are enshrined in Article 17 of the Law on the Rights of Patients, but the general functioning of this fund is envisaged in the Regulation No. 1268 of the Cabinet of Ministers of the Republic of Latvia from November $5^{\text {th }} 2013$ "Functioning rules of the Medical risk fund" [17].

The institutional structure of the Medical risk fund is dual, i.e., its functioning is ensured by two institutions that are directly subordinated to the Ministry of Health: the Health Inspectorate (which provides expertise, prepares legal opinions, determines the extent of the compensation in percentage and evaluates the relation of the incurred medical expenses with the mitigation or prevention of the harm inflicted to the patient) and the National Health Service (which administers the Medical risk fund assets and on the basis of the legal opinion of the Health Inspectorate decides either to pay or refuse compensation to the patient from the assets of this fund). The decision or factual conduct of the National Health Service regarding the payment of compensation from the Medical risk fund may be challenged before the Ministry of Health and the decision of the Ministry of Health in its part may be appealed in court in accordance with the Administrative Procedure Law. 
However, the patient is not entitled to challenge or appeal the legal opinion of the Health Inspectorate.

Discussing the legal nature of the Health Inspectorate's legal opinion, it can be concluded that it is neither an administrative act nor an interlocutory act in the administrative proceeding, but must be considered as the evidence - a legal opinion of an expert. Firstly, this evidence is characterized by persons who prepare it - persons who have specific knowledge and who give a specific opinion on a particular case, for whose evaluation this specific knowledge is required. Neither the Law on the Rights of Patients nor the Functioning Rules of the Medical risk fund provide for a procedure in cases when the legal opinion of the Health Inspectorate is inadmissible or improbable as the evidence (considering that it is unlikely that a disagreement could arise of the relevance of this kind of evidence). In any other type of proceedings, in the case when reasonable doubts arise it is possible to appoint an additional or repeated expertise to eliminate them.

When interviewing the responsible controlling officials (on June $26^{\text {th }} 2015$ the authors interviewed officials of the Ministry of Health who are involved in preparing the decisions regarding appeals against the decisions of the National Health Service), it was found that in cases when the legal opinion of the Health Inspectorate is not entirely clear or is incomplete and when, consequently, in regard to this legal opinion additional questions have emerged, during the appeal process the officials of the Ministry of Health take measures which are considered as a repeated expertise. Namely, if in its legal opinion the Health Inspectorate has not given assessment on some circumstances of the case, if new evidence has been submitted during the appeal procedure or if some conclusions of the opinion are controversial, the Ministry of Health requests to the Health Inspectorate to give a legal opinion to the circumstances that have not been analysed previously. Although such an action is not procedurally defined, in accordance with ratio legis such an action is to be qualified as a repeated expertise.

However, there is not a clear and understandable legal mechanism for appointing a repeated expertise (for comparison, such legal basis are provided in Article 182, paragraph 3 of the Administrative Procedure Law [11], Article 197 of the Criminal Procedure Law [15] and Article 125, paragraph 3 of the Civil Procedure Law [13]) in cases such as: an unreasonable legal opinion of the Health Inspectorate, significant deficiency or methodological mistakes, expert's lack of qualification, incompetence or other incompatibilities. The officials of the Ministry of Health pointed out that so far such situations have not occurred. Nevertheless, from the viewpoint of the protection of patients' rights, the lack of regulation regarding additional or repeated expertise is a step back.

With the implementation of the Directive, Paragraph 8.3 of the Rules of Functioning of the Medical risk fund provides the Health Inspectorate a right to "request to a commission (with no less than three medical practitioners and, if additional assistance is required, by inviting specialists from other medical institutions) which is formed by the head of the medical institution (for which actions the compensation is requested in the patients complaint) to provide an evaluation and opinion on the harm inflicted to the patient and the extent of it". From the authors' point of view, such a regulation, which basically provides that the violator of patient's rights evaluate its own mistakes, is nothing more than a legislative defect. In relation to this it must be pointed out that already in the Roman law there was developed the principle of nemo iudex in causa sua (no one should be a judge in his own case).

It should be noted that until June $27^{\text {th }} 2015$ the Health Inspectorate has not exercised this regulation yet. In the authors' opinion, the relevant regulation does not comply with the fundamental right to a fair trial (Article 92 of the Constitution of the Republic of Latvia [4, 14]. Meanwhile, until June $27^{\text {th }} 2015$ the National Health Service had received 108 submissions of compensation claims (from which 11 were refused, 1 was withdrawn and 1 
was found as not filed). Regarding the submitted complaints in 8 cases the National Health Service decided to pay compensation to the patient, in 24 cases it decided to refuse the claim of compensation, from which 5 have been challenged before the Ministry of Health for the decision to refuse the claim of compensation and in 1 case challenged for the decision to refuse examination of the submitted claim [26].

At this moment, there are too few decisions of the National Health Service in which it has decided to pay compensations to patients, in order to make any assessment regarding effectiveness of the new system.

Concerning the implementation of the Medical risk fund concept, it must be noted that also here there has been a change of procedural principles. Civil procedure principles such as the adversarial principle and the principle of equality of arms have been replaced by the principle of objective investigation and other administrative procedure principles. The patient is no longer entitled to choose experts, to express an opinion on preferred candidatures of experts, to ask questions to experts or to get acquainted with the experts' qualification which in many cases is the most important issue during the stage where expertise is appointed. At the same time, according to Article 37, paragraph 2 of the Administrative Procedure Law there still remains the patient's right to apply a recusal to an expert.

The sums of compensation, to which the patient is entitled for the harm inflicted to his life and health, are determined by the court and at the discretion of the court (Article 5 of the Civil Law of the Republic of Latvia). Since October $25^{\text {th }} 2013$ this matter is regulated in accordance with the Rules of Functioning of the Medical risk fund. Determination of the severity of moral injury in percentage, which is specified in a legal norm, is a new approach to this matter in Latvia. In this case, a clear gain is the legal certainty, because on the same factual conditions there will be an equal compensation, thereby excluding the so-called human factor in the evaluation. However, at the same time here disappears the advantage of the discretion of the court, which individualised each particular case and envisaged to determine the amount of compensation according to the purpose and aim of Article 1635 of the Civil Law of the Republic of Latvia - for the physical and mental suffering which is individual for each person and not the same for everybody.

Also in Sweden and Denmark, on whose basis the Medical risk fund has been implemented in Latvia, compensations are paid for: (1) damages - loss of income, loss of pension, medical treatment expenses; (2) non-pecuniary damages - for pain and suffering (for example, in Denmark - 130 Danish kronor for each day of illness), for disability, for mutilation, for incapacity to work. The compensation for disability is paid as a lump sum. In Sweden such compensation is determined in accordance with a table approved by the Commission of Road Traffic Accidents, which is used by all Swedish insurance companies and courts [2]. This data shows the reason for excluding the discretion of the court in the administrative stage (to which public institutions also cannot be assigned) regarding the determination of the compensation to patient.

It should be noted that while performing an expertise the Health Inspectorate uses only the patient's medical documents, but does not proceed with an interview or an examination of the patient himself. Basically, during this process the patient is entitled to express himself only once, when submitting his complaint to the National Health Service. This can be regarded as an ignorance of the principle of objective investigation. It was concluded previously that so far in Latvia the court practice development in the aspect of the civil liability of medical practitioners cannot be evaluated unambiguously by the fact that in court rulings the court does not evaluate the multifactorism of failed medical treatment causalities. By transferring failed medical treatment causality evaluation from courts, that are independent bodies from the executory power of medical institutions, to a directly subordinated institution, the Health Inspectorate, and, in addition, not providing any other 
causal forms than only conditio sine qua non in the Rules of Functioning of the Medical risk fund, one cannot expect a deeper understanding in causal matters and hope for a positive development in healthcare violation cases.

Respectively, the primary aim of the Medical risk fund is to protect the patient. However, it has to be admitted that a completely different aim will be accomplished very effectively - to protect medical institutions and medical practitioners from negative pecuniary consequences in cases of a professional failure or negligence. It is going to be so, because the functioning of the Medical risk fund is based on the principle of mandatory insurance concept, as a result of which the pecuniary liability of medical institutions and practitioners according to Article 16, paragraph 2 of the Law On the Rights of Patients is limited to 142290 euros for the harm inflicted to patient's life and health (also nonpecuniary damage) and to 28460 euros for the patient's medical treatment expenses. However, a question arises how the patient should act in cases when $\mathrm{s} /$ he considers that the compensation limits provided for in Article 16, paragraph 2 of the Law on the Rights of Patients do not compensate the inflicted harm in full. In such situations the patient is entitled to file a civil claim in court. Consequently, it can be concluded that medical institutions and practitioners shall be excluded from negative pecuniary consequences in cases of a professional failure or negligence only if the patient shall be satisfied with the compensation sums paid out from the Medical risk fund.

At the same time, it must be remembered that the aim of the Medical risk fund, as defined by the Directive, is to ensure that for the patients there are available and transparent complaint submission procedures and mechanisms, which allow patients to seek remedies in accordance with the regulations of the respective Member State, in cases when the healthcare provided has inflicted harm to him. The aim of the Directive cannot be achieved if the limits of compensation provided for in Article 16, paragraph 2 of the Law on the Rights of Patients do not fully compensate inflicted harm to the patient.

Regarding this matter, the place of the disposition (or personal autonomy) principle in the Rules of Functioning of the Medical risk fund must also be discussed when implementing the concept of this fund. Annex 1 of these rules does not provide for the applicant to specify, among other information, the sum of money which they consider to be an adequate compensation for the harm inflicted to their life or health.

Returning to the matter of the primary aim of the Medical risk fund - to protect the patient - it must be noted that in cases when patient will be satisfied with the decision of the National Health Service and shall not challenge it before the Ministry of Health and/or appeal it to the court, then this aim shall be achieved. Otherwise such proceedings are simply going to be longer in comparison to civil proceedings.

\section{Conclusions}

The patient's right to submit complaints is considered as patient's procedural right which also provides an opportunity to protect other patient's rights in cases when such patient's rights are not ensured. During the period from March $1^{\text {st }} 2010$ until April $18^{\text {th }} 2012$ the scope of patient's right to submit applications to administrative courts was significantly narrowed.

By adopting Article 18, paragraph 3 of the Law on the Rights of Patients, a legislative mistake was made, providing in the relevant regulation that the reply of Health Inspectorate to a complaint filed by a patient must be given in accordance with the Law on Submissions, arguing that the patient's complaint belongs to the subjective public law which serves as an individual legal remedy for the patient. The authors believe that the respective regulation 
must be amended, by excluding the reference that the appeal must be made in accordance with the Law on Submissions.

The court practice in healthcare violation cases is not unambiguous. The primary consequence of such court practice is directly connected with the confidence of society in the actions of the court. A secondary problem is that persons cannot safely conduct their activity: the persons must be able - if need be, by receiving advice from a specialist - to predict the consequences of their actions in a reasonable way.

The courts by themselves cannot evaluate the reasonableness of medical conclusions of the Health Inspectorate without special knowledge in medical science. It should not be allowed that the courts distance themselves from evaluation of medical matters in general. However, judges should not be specialists in all branches of science. Still, in unclear matters the courts should make use of the available procedural instruments such as an additional expertise and/or a repeated expertise, consequently interrogating the relevant experts.

Considering that case in which the Health Inspectorate has acknowledged that there has not been a violation of healthcare, are reviewed in the court of first instance, it is especially important to appoint an additional expertise and/or a repeated expertise to eliminate any doubts regarding the possible violation of healthcare, if such circumstances are in dispute.

A measure to determine whether an additional expertise or a repeated expertise should be appointed can be found in the existing argument from court practice regarding the lack of correlation between the information provided and the conclusions made.

The Medical risk fund concept replaces the traditional civil liability model of medical practitioners. The Medical risk fund is both a specific insurance institute and a legal remedy for the protection of patients' rights.

Until the introduction of the Medical risk fund in Latvian legal order, which determines the extent of the compensation, there dominated the discretion of the court model, but since the introduction of this concept the severity of the moral injury in percentage is determined in accordance with legal acts. Determination of the severity of moral injury in percentage, which is specified in a legal norm, is a new approach to this matter in Latvia.

The civil law principles governing civil liability of medical practitioners have been replaced with administrative procedure principles, giving a central role to the Health Inspectorate who has the competence both to perform expertise and to determine the compensation for the moral injury in percentages.

At this moment, there are too few decisions of the National Health Service in which it has decided to pay compensations to patients, in order to make any assessment regarding effectiveness of the new system.

By transferring failed medical treatment causality evaluation from independent courts to a directly subordinated institution, the Health Inspectorate, and by not providing any other causal forms than only conditio sine qua non in the Rules of Functioning of the Medical risk fund, one cannot expect an understanding in causal multifactorism matters in healthcare violation cases.

From the point view of the protection of patients' rights, the absence of any regulation regarding appointment of additional or repeated expertise in relation to the expertise provided by the Health Inspectorate within the framework of the Medical risk fund concept, must be considered as a significant deficiency.

The Rules of Functioning of the Medical risk fund confer a right to the Health Inspectorate to demand for the head of the medical institution, for which actions the compensation is requested by the complaint of the patient, to appoint a commission and to provide an evaluation as well as an opinion on the harm inflicted to patient and the extent of it. Such a provision does not comply with the content of the principle of nemo iudex in causa sua (no one should be a judge in his own case) and the right to a fair trial. 
The aim of the Medical risk fund, as defined by the Directive, is to ensure that for the patients there are available and transparent complaint submission procedures and mechanisms, which would allow patients to seek remedies in cases when the healthcare provided has inflicted harm to them. The aim of the Directive cannot be achieved if the limits set by Article 16, paragraph 2 of the Law on the Rights of Patients do not fully compensate the inflicted harm to the patient.

\section{References}

1. U. Mitenbergs, M. Taube, J. Misins, E. Mikitis, A. Martinsons, A. Rurane, W. Quentin. Latvia: Health system review. Health Systems in Transition, 2012, 24 (2012)

2. Cabinet of Ministers regulation, "The Medical risk fund functioning rules" the projects initial (ex-ante) impact report [http ://WWW. vm . gov. lv/images/ userfiles/phoebe/aktualitates_publiska_apspriesana_6ad08 b8ff5eb59abc2257b0200464996/vmanot_210513_arf.docx (seen on 05.06 .2015$)$ ]

3. Charter of fundamental rights of the European Union, 18.12.2000 Official Journal of the European Communities C 364/1 [http://Www europar l, europa, eu/ charter/pdf/text_en.pdf (seen on 01.06.2015)]

4. Convention for the Protection of Human Rights and Fundamental Freedoms. The Council of Europe [http://conventions. coe. int/Treaty/en/ Treaties/Html/005.htm (seen on 01.06.2015)]

5. Draft law "Amendments of the Law on Submissions" annotation [http://titania. saeima. lv/LIVS11/SaeimaLIVS11.nsf/0/8507 65853B51A05EC2257936004A132C?OpenDocument (seen on $02.06 .2015)]$

6. European Charter of Patients' Rights [http://ec . europa. eu/health/ ph_overview/co_operation/mobility/docs/ health_services_col08_en.pdf (seen on 01.06.2015)]

7. Law On Submissions [http://wWw, vvc gov, lv/export/sites/ default/docs/LRTA/Likumi/Law_On_Submissions.doc (seen on 02.06 .2015 ) ]

8. Law On the Rights of Patients [http://WWw vVC.gov. lv/export/ sites/default/docs/LRTA/Likumi/Law_on_the_Rights_of_ Patients.doc (seen on 01.06.2015)]

9. Medical Treatment Law

[http://WWW.VVC.gov, lv/export/sites/default/docs/LRTA/ Likumi/Medical_Treatment_Law.doc (seen on 01.06.2015)]

10. Regulations of the Health Inspectorate [ht $\mathrm{t}: / / \mathrm{vi}$.gov. lv/en/start/ _142/regulations-of-the-health-inspectorate (seen on 01.05 .2015 )]

11. The Administrative Procedure Law [http://www. vvc.gov. IV/export/ sites/default/docs/LRTA/Likumi/Administrative_Procedure_ Law.doc (seen on 01.06.2015)]

12. The Civil Law

[http://WWW.Vvc.gov, lv/export/sites/default/docs/LRTA/ Likumi/The_Civil_Law.doc (seen on 01.06.2015)] 
13. The Civil Procedure Law

[http://WWw. VVC gov, lv/advantagecms/docs/LRTA/Likumi/ Civil_Procedure_Law.doc (seen on 01.06.2015)]

14. The Constitution of the Republic of Latvia

[http://WWw.Vvc.gov. lv/export/sites/default/docs/LRTA/

Likumi/Constitution.doc (seen on 02.06.2015)]

15. The Criminal Procedure Law

[http://WWW.VVC.gov, lv/export/sites/default/docs/LRTA/

Likumi/Criminal_Procedure_Law.doc (seen on 01.06.2015)]

16. The Latvian Administrative Violations Code

[http://wWw, VVc.gov. lV/export/sites/default/docs/LRTA/

Likumi/Latvian_Administrative_Violations_Code.doc (seen

on 01.06 .2015 )]

17. The Medical risk fund functioning rules. Cabinet of Ministers. Adopted 05.11.2013. [Came into force 23.11.2013] (Official Journal "Latvijas Vēstnesis", 228 (5034), 22.11.2013) [http://likumi,lv/doc,php?id=262102 (seen on $01.06 .2015)]$

18. The Supreme Court of Latvia Senate the Department of Administrative cases October 25, 2013 judgement in case No. SKA-0340-13 (A420430312)

[http://www.tiesas. lv/nolemumi/pdf/130711.pdf (seen on 04.05 .2015 ) ]

19. The Supreme Court of Latvia Senate the Department of Administrative cases December 17, 2010 judgement in case No. SKA-1032/2010 (A7033910/2) [http://at.gov. lv/files/uploads/files/archive/department 3/2010/ska_1032_2010.pdf (seen on 04.06.2015)]

20. The Supreme Court of Latvia Senate October 16, 2008 judgement in case No. SKA411/2008 para. 9 .

[http://WWW tiesas. lv/files/AL/2008/10_2008/16_10_2008/ AL_1610_AT_SKA-0411_2008.pdf (seen on 04.05.2015)]

21. The Supreme Court of Latvia Senate the Department of Administrative cases October 15, 2010 judgement in case No. SKA-334/2010 para. 8.

[http://WWw, tiesas.lv/files/AL/2010/10_2010/15_10_2010/ AL_1510_AT_SKA-0334-2010.pdf (seen on 04.06.2015)]

22. The Supreme Court of Latvia Senate the Department of Administrative cases February 24, 2012 judgement in case No. SKA-64/2012 para. 11.

[http://wWw.tiesas.lv/files/AL/2012/02_2012/24_02_2012/ AL_2402_AT_SKA-0064-2012.pdf (seen on 04.06.2015)]

23. The Supreme Court of Latvia the Chamber of Civil Cases June 17, 2010 judgement in case No. PAC-0371 (C04211805) [not published]

24. The Regional Administrative Court June 10, 2010 judgement in case No. A42461207

[http://www. 12d,lv/v,php?i=16229 (seen on 05.06.2015)]

25. The District Administrative Court July 12, 2013 judgement in case No. 142251012 (court of appeal upheld the judgement)

[http://Www tiesas. lV/Media/Default/Admin.tiesu\%20spried umi/Admin.raj . tiesas\%20spriedumi/2013/J\%C5\%ABlijs/12.07. 2013/AL_1207_raj_A-00849-13_26.pdf (seen on 05.06.2015)]

26. The letter from National Health Service from July 6, 2015 